\title{
Working
}

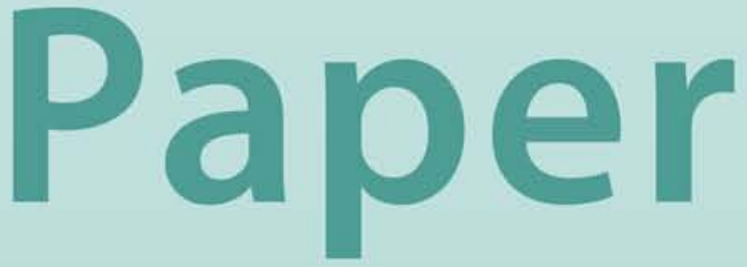




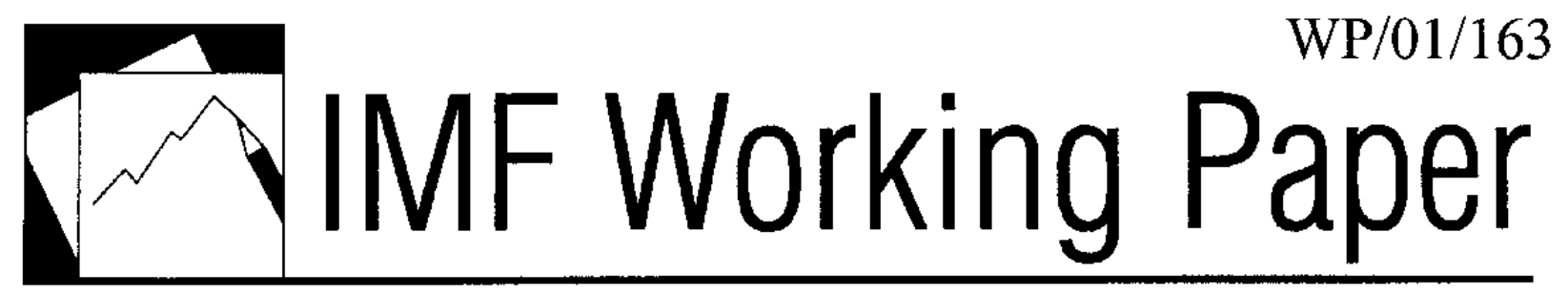

\section{Trade in the Mashreq: An Empirical Examination}

Rodolphe Blavy 


\title{
IMF Working Paper
}

\author{
Middle Eastern Department
}

\section{Trade in the Mashreq: ${ }^{1}$ An Empirical Examination}

\author{
Prepared by Rodolphe Blavy ${ }^{2}$
}

Authorized for distribution by Klaus Enders

October 2001

\begin{abstract}
The views expressed in this Working Paper are those of the author(s) and do not necessarily represent those of the IMF or IMF policy. Working Papers describe research in progress by the author(s) and are published to elicit comments and to further debate.
\end{abstract}

This paper provides a framework for understanding trade patterns in the Mashreq. An augmented gravity model is used to compare actual with expected levels of trade. Trade barriers, political uncertainty, and over-appreciation of domestic currencies seem to explain low levels of international trade. At the intra-regional level, specific trade barriers between Israel and other Mashreq countries reduce further levels of trade. Quite surprisingly, removing Israel from the sample leads to higher actual intra-regional trade than predicted. The analysis suggests that trade liberalization, correction of currency misalignments, reduction of political uncertainty, and improved trade relations with Israel would boost trade in the region.

\section{JEL Classification Numbers:C10, F13, F15, O11, R58}

Keywords: Egypt, Israel, Jordan, Lebanon, Mashreq, Syria, gravity model, trade policy Author’s E-Mail Address: rapb2@hermes.cam.ac.uk

\footnotetext{
'For purposes of this paper, the Mashreq countries include Egypt, Israel, Jordan, Lebanon, and Syria; data limitations keep us from including the West Bank and Gaza in our sample.

${ }^{2}$ The paper was prepared while Rodolphe Blavy was working as a summer intern in the Fund's Middle Eastern Department in the summer/fall of 2000. I wish to thank colleagues in the Middle Eastern Department for valuable comments. Ms. Ilse-Marie Fayad, Ms. Aminata Toure, and Farhan Hameed provided valuable research assistance.
} 


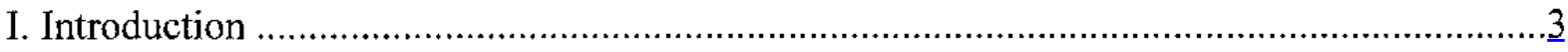

II. Trade Patterns in the Mashreq......................................................................................

III. Model specification and Normal levels of trade in the Mashreq .....................................

A. Standard Gravity Model...............................................................................

B. Explaining Low Levels of Trade in the Mashreq: An Augmented Specification of the Gravity Model ..........................................................................................

IV. "Normal Levels of Trade" in the Mashreq ....................................................................10

A. Exchange Rate, Trade Restrictions, and Political Risk: Where Does the Mashreq Stand?

B. Assessing Levels of International Trade in the Mashreq .......................................11

C. Israel and Low Levels of Intra-Regional Trade ..............................................12

D. Limits and Qualification of the Results ...........................................................13

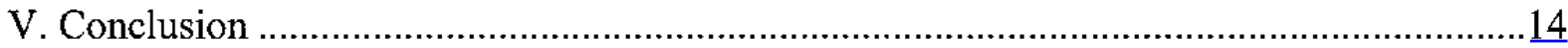

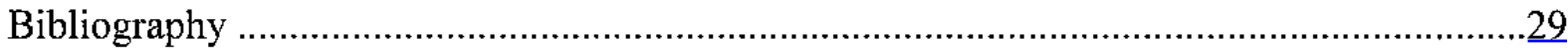

Text Tables

1. Mashreq and Comparators: Global Trade Indicators..............................................16

2. Intra-Regional Trade in the Mashreq region........................................................17

3. Estimates for the Augmented Specification........................................................18

4. Sample Averages and Mashreq values on Control Variables ......................................19

5. Mashreq and Comparator Countries: Trade Restrictions, 1999.................................20

6. Estimates for the Augmented Specification with Mashreq Dummies .........................21

7. Estimates for the Augmented Specification with Mashreq Dummies

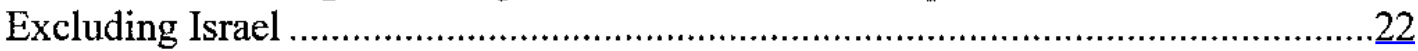

8. Trade Intensity Index for Exports in the Mashreq ..................................................23

9. Comparison: Expected vs. Real Intra-Regional Exports ……..................................24

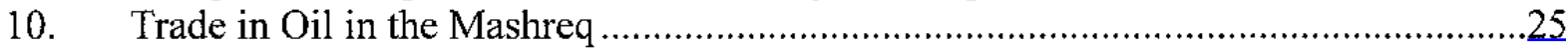

Appendices

I. Estimates for Individual Years, Excluding Regional Dummies ................................26

II. Estimates for Individual Years, Including Mashreq Dummy Variables .....................27

III. Countries Included in the Gravity Model Sample .................................................28 


\section{INTRODUCTION}

Trade patterns in the Mashreq are characterized by a few stylized facts: (a) the integration of Mashreq economies into international trade remains limited; (b) intra-regional trade is at very low levels, especially when compared with other regions; and (c) exports are concentrated in oil-related products and labor-intensive goods. Several reasons may explain why the Mashreq economies appear to be little integrated into the international economy: (a) real exchange rates are high and have tended to appreciate in recent years; (b) trade restrictions in the Mashreq are higher than in other developing regions; and (c) political uncertainty affects long-term trading relations. Additional factors may limit intra-regional trade, from the lack of product complementarity to political tensions in the Mashreq. To investigate the role of real exchange rates, political uncertainty, and trade restrictions, we propose to quantify "normal levels of trade" for the Mashreq using a gravity model. This type of model has been used in previous similar studies and, while it has well-known theoretical limits, we find that the model is robust and represents a useful empirical tool.

To date there seems to have been little investigation of trade in the Mashreq based on practical experience using a gravity model framework. In particular, no empirical study has focused directly on the Mashreq region, that is, Egypt, Israel, Jordan, Lebanon, Syria, and the West Bank and Gaza. ${ }^{3}$ The study closest to the subject is the $1999 \mathrm{Al}$-Atrash and Yousef (2000) assessment of intra-Arab trade. In their study, the definition of the Mashreq introduced a positive bias to the results, as they include Sudan, and exclude Israel. Because Israel, with almost no intra-regional trade, is close to other Mashreq countries, and because Sudan, which is much further away than Israel, trades relatively more with the Mashreq, the Mashreq dummy is biased upward, and found positive. Moreover, previous studies do not control for variables that may be important for trade in the Mashreq. Previous models use the standard gravity equation, augmented with a few variables that apply to trade patterns globally, and may not specifically shed light on trade patterns in the Mashreq. Those variables range from a number of proxies for "resistance to trade" and "size of the economy" (linguistic or cultural similarity, island, area, or other similar substitutes) to variables directly related to trade such as dummies for free-trade agreements (FTA). We use the standard gravity equation as our base model. Our estimations prove both its robustness and its explanatory power. We augment it with variables that may be important for trade in the Mashreq: trade restrictiveness, real exchange rate, and political risk. Arguments to explain low levels of trade in the Mashreq may be captured and assessed with these variables.

The main finding of the paper is empirical evidence that (a) trade restrictions, (b) political instability, and (c) levels of exchange rates are major factors limiting international trade in the Mashreq. After controlling for those variables, international trade is at expected

\footnotetext{
${ }^{3}$ Havrylyshyn (1997) and other studies of trade issues focus on the Middle East and North Africa (MENA) region as a whole: World Bank (1993), Deardoff (1995), and Ekholm and others (1995).
} 
levels in the region. At the regional level however, the three control variables explain only partially low levels of trade. The specific relationship between Israel and the Arab countries of the Mashreq is confirmed to be the main limit to intra-regional trade. Without Israel, regional trade is higher than predicted by the gravity model, due notably to strong trade relations between Syria and Lebanon.

Limits to the findings on intra-regional trade must be noted from the start. The paper does not establish and analyze bilateral indicators, whether they be trade restrictions, exchange rate movements, or political relations. For Mashreq countries, it seems fairly probable that all three variables may be significantly different when measuring bilateral values compared to multilateral ones. Further research may attempt to pursue this issue, while the present paper gives an initial understanding of the factors important to intra-regional trade in the Mashreq.

The paper is organized as follow: Section II reviews patterns of international and intraregional trade in the Mashreq; Section III develops the "gravity model" specification and assesses normal levels of trade in the Mashreq; Section IV presents a tentative explanation for low levels of trade in the Mashreq, using the gravity model as an analytical tool; while Section $\mathrm{V}$ focuses on the results and their implications concerning trade policy.

\section{Trade Patterns in the MashreQ}

Integration into the world economy measured by trade has developed in strikingly different ways in the Mashreq from comparator regions in Asia and Latin America. Over the last two decades the Mashreq (excluding Israel) has lost one-half of its share in world exports, similar to the Maghreb (i.e., Algeria, Morocco, and Tunisia), while developing countries as a whole broadly held their share constant. At the same time, Israel increased its share of exports by 50 percent, while East Asia doubled its share (Table 1). As a result, the share of the Mashreq region in world exports in 1999 was less than 1 percent, and only 0.2 percent when Israel is not included.

As measured by the share of trade in GDP, the Mashreq region has in fact become less open between 1980 and 1999. ${ }^{4}$ Only Jordan and the West Bank and Gaza experience levels of openness that are comparable to the average developing country (70 percent of GDP). When only exports are considered, the gap is even wider, with exports amounting to 13.4 percent of GDP in Mashreq countries (excluding Israel, where exports as a percent of GDP reach 26.1 percent) compared to 37.1 percent in the average developing country.

\footnotetext{
${ }^{4}$ The contraction of trade relative to GDP in Egypt (and Lebanon, where factors related to the war are an obvious explanation) basically reflect unchanged exports while, with high domestic inflation and an unchanged exchange rate, GDP rose sharply in foreign currency terms.
} 
Intra-regional exports in 1999 reached only 1.6 percent of total exports (Table 2). Israel has almost no trade with its Mashreq neighbors (excluding WBG). ${ }^{5}$ Levels of intra-regional exports in the Mashreq are much below, say, intra-European or intra-African trade, and even below intra-MENA trade. Of course, these data are not strictly comparable given the very different size, diversity, and levels of development of the regions involved. A more legitimate comparison would be with intra-Maghreb trade, which is far lower than intra-Mashreq trade. Intra-regional exports as a percentage of total exports have been declining significantly in the region since 1995, from 3.2 percent in 1995 down to 1.6 percent in 1999.

\section{MODEL SPECIFICATION AND NORMAL LEVElS OF TRADE IN THE MASHREQ}

Gravity models were introduced to economic theory in the 1960s. Linneman's (1969) seminal study applied an econometric model to analyze the factors that explain trade for a sample of 80 countries. The explanatory power of Linneman's model was limited by several factors - one being that of a political nature, referred to as "psychic distance" by Beckerman (1956), which Linneman does not take into consideration. Political distance could notably be explained by divergence of political regimes, political conflicts between two countries, domestic political uncertainty. Another limit was that Linneman did not take into account economic alliances and regional trade agreements. Following studies have attempted to diminish those limits.

Gravity models have been augmented with variables representing political resistance to trade. Pollins (1989) explicitly incorporates foreign policy orientation in a model to explain bilateral trade, using a gravity model in which the resistance factor is augmented by measures of international conflict and cooperation. In focusing on the period 1960-75, his findings support the assumption that political relationships are an important determinant of trade. With the development of regional trade agreements, or preferential trade agreements (PTA), other studies have attempted to quantify the effects of PTA on bilateral trade (Frankel and others, 1996a, 1996b). To the standard formulation of the gravity equation, they add regional dummies to test for trade bloc effects. Although results are mixed, they find that intra-bloc biases exist for such organizations as the European Community, MERCOSUR, the Andean Pact, the Association of Southeast Asian Nations (ASEAN), and larger regional groups including Europe, the Americas, and Asia.

While gravity models have usually been seen as robust empirical models with little theoretical justification, Helliwell (1998) summarizes recent attempts at building theoretical foundations to the model. Among such approaches, the Heckscher-Ohlin theory of trade has been used as theoretical justification for the gravity equation (for example, Deardoff, 1995). Second, theories of trade based on product differentiation have been used (Helpman, 1984, and Bergstrand, 1985). Bergstrand (1985) provided some theoretical and empirical evidence that the

\footnotetext{
${ }^{5}$ There is substantial trade between Israel and WBG, which however is not recorded as foreign trade in the DOT statistics underlying the analysis of this paper. Trade between the WBG and other countries outside Israel is not recorded in DOT statistics on foreign trade of Israel.
} 
gravity equation is "a reduced form from a partial equilibrium sub-system of a general equilibrium model with nationally differentiated products." (Bergstrand, 1985, p. 474) Anderson (1979) derives the gravity equation from the properties of expenditure systems, starting with a simple rearrangement of the Cobb-Douglas expenditure system.

The gravity model remains, however, a highly stylized model that leaves out many factors. In the sequel, a simple version is used to provide an empirical benchmark for assessing trade in the Mashreq relative to the "typical" experience of the "average" country.

\section{A. Standard Gravity Model}

We use a simple model specification to assess determinants of bilateral trade. The standard gravity equation in multiplicative form is:

$$
X_{i j}=\alpha_{0} Y_{i}^{\alpha_{1}} Y_{j}^{\alpha_{2}} N_{i}^{\alpha_{3}} N_{j}^{\alpha_{4}} D_{i j}^{\alpha_{5}} \varepsilon_{i j}
$$

Where:

$X_{i j}$ are exports from country (i) to country (j)

$Y_{i}$ is the GDP in the exporting country

$Y_{j}$ is the GDP in the importing country

$N_{i}$ is the population in the exporting country

$N_{j}$ is the population in the inporting country

$D_{i j}$ is the distance between the two countries.

$\varepsilon_{i j}$ is a normally distributed error-term, with $\mathrm{E}\left(\varepsilon_{i j}\right)=1$ We linearize using logs and add a border dummy, which takes the value 1 if two countries share a common border and 0 otherwise.

$$
\ln \left(X_{i j}\right)=\alpha_{0}+\alpha_{1} \ln \left(Y_{i}\right)+\alpha_{2} \ln \left(Y_{j}\right)+\alpha_{3} \ln \left(N_{i}\right)+\alpha_{4} \ln \left(N_{j}\right)+\alpha_{5} \ln \left(D_{i j}\right)+\alpha_{6} \text { border }+\ln \left(\varepsilon_{i j}\right)
$$

The endogenous variable of the model is the level of bilateral export flows in U.S. dollar terms. We use data from the IMF Direction of Trade (DOT) database as of September 2000. Ideally, it would be preferable to use trade volume rather than values. However, data on bilateral export (or import) volumes are not available and deflating trade values with some aggregate price measure (e.g., the U.S.-Consumer Price Index) would introduce its own biases.

Another measurement problem arises because very small trade flows are recorded as zeros. The multiplicative form of the equation cannot accommodate variable values of zero without losing its explanatory power. One solution is to omit all zero observations from the sample. This would however lead to the deletion of ten percent of our sample. In addition to a 
potential loss of explanatory power, it would introduce a significant survivorship bias since only significant bilateral trade flows would be studied. To diminish this problem, we replace all zero bilateral trade values by small values, i.e. 0.005 , which is half of the smallest recording import data recorded in the DOT database, US\$0.01 million. Whenever data is not recorded, we treat observations as randomly distributed missing data.

Distance is measured in miles and corresponds to the distance between the two countries' capitals. Population is measured in millions inhabitants, and GDP figures in billions of U.S. dollars. ${ }^{6}$ The use of GDP and population variables in the same specification introduces a risk of multicollinearity in the variables. We test for multicollinearity by assessing the correlation between the two explanatory variables. A general rule of thumb for detecting the presence of multicollinearity is that if the correlation coefficient between two variables is greater than 0.8 (or 0.9 ), then multicollinearity is a serious problem. We find that the correlation between the GDP regressor and the population regressor is always inferior to 23 percent, which is far below the usual threshold. ${ }^{7}$

We define our sample as the whole population of countries, excluding very small economies, as defined by:

- Gross domestic product (GDP) greater than US\$5 billion;

- Total population greater than 2 million;

- GDP per capita greater than US\$500.

The resulting sample comprises 82 countries (Appendix II). Since all countries of significant economic and demographic size under the above definition are included, problems of statistical significance are less acute than with representative sample testing. Our results may, however, not be used to explain and predict trade patterns for the least advanced countries (with low GDP and low GDP per capita, as defined using the criterion thresholds), nor for very small countries (islands or small independent territories). This choice is consistent with the Mashreq economies, classified as middle-income economies in the World Bank classification. The West Bank and Gaza is the only Mashreq economy that may not be described correctly by our empirical estimates since it falls below our economic and demographic size limits.

\footnotetext{
${ }^{6}$ The use of one variable for the size of the country (a population or economic size variable) and of another variable for the level of economic development (typically the level of GDP per capita) is rejected because of the multicollinearity that would arise between the two variables.

${ }^{7}$ Another method is to regress one of the variables on the remaining ones. In our model, the resulting $\mathrm{R}^{2}$ is lower than 50 percent, and the presence of multicollinearity is again rejected.
} 
Coefficients are estimated using linear regression with pooled data. The model is run with pooled data over three periods: 1990-95, 1995-99, and 1997-99 (first three columns of Table 3). In the 1997-99 period of reference, 19,929 observations are included. The samples for the two other periods consist of 33,220 observations. We run the same model for each individual year, from 1990 to 1999 , with 6,644 observations each year-the results proving to be very close to those reported for pooled data (Appendix I).

\section{B. Explaining Low Levels of Trade in the Mashreq: An Augmented Specification of the Gravity Model}

Four traditional factors may explain low levels of international and intra-regional trade in the Mashreq. First, trade restrictions are among the highest in the world. Second, the real appreciation of exchange rates throughout the $1990 \mathrm{~s}$, and the subsequent loss in competitiveness may provide a major constraint to international trade for the Mashreq. Third, political tension in the region may be a factor limiting intra-regional or even international trade. ${ }^{8}$

We model trade restrictiveness for the reporting country and for the partner country. Trade restrictiveness is represented by the IMF trade restrictiveness index, which provides a ranking from 1 to 10 of the degree of trade restrictions. ${ }^{9}$ Because the index is available only from 1997 (for details on its construction see Sharer and others, 1998), it restricts our estimation period from 1997 to 1999 . The index measures restrictions to trade overall, including both restrictions to exports and restrictions to imports.

The International Country Risk Guide (ICRG) index for political risk is used as a proxy for the influence of political tension in the Mashreq. Risk ratings from the ICRG give indications of the perception of risk from foreign direct investors. Data is available from January 1984 to April 2000 for all Mashreq countries except the West Bank and Gaza. The

\footnotetext{
${ }^{8} \mathrm{~A}$ fourth factor, the lack of product complementarity has sometimes been quoted as a limit to intra-regional trade in the Mashreq. The relative similarity of resources (oil and agricultural products) and factor endowments (unskilled labor) limit trade flows based both on product differentiation and on comparative advantage (see for example Yeats, 1996). However, it appears difficult to break each bilateral trade flow (i.e., each of the 6,644 recorded flows) along product lines, to account for product complementarity. Moreover, theoretical discussions on the role of product complementarity in the Mashreq have been inconclusive. Fischer (1993) and others argue that lack of product complementarity may be a limit to bilateral trade. On the other hand, Havrylyshyn (1997), using a complementarity index, suggests that product complementarity in the Mashreq compares favorably with other regions. Further research may attempt to develop measures of product complementarity between countries to assess its impact on trade.

${ }^{9}$ The Trest variable that we include in the model specification is a "threshold" variable. However, even though the use of threshold variables may be inadequate, the alternative is to use dummy variables accounting for each threshold; in our case nine dummies are required for each level of trade restriction, except for the base level. For this reason, we decided here to use the Trest variable as such, because its levels measure directly quantitative levels (how much trade restriction in the reporting country). The underlying assumption is that the increment in bilateral trade at each threshold is the same. Testing for standard assumptions of linear regressions, we found that both linearity and normality conditions were satisfied for the Trest variable.
} 
ICRG index ranges from 0 to 100 and adds up scores on 24 indicators, each associated with a maximum value. The highest number of points (rating) corresponds to the lowest potential risk, the lowest number of points (0) corresponds to the highest potential risk. The indicators for political risks and the respective maximum number of points for each component are (in the ICRG's own terminology): economic expectations vs. reality (12), investment profile (12), political leadership (12), external conflict (10), corruption in government (6), military forces in politics (6), law and order tradition (6), racial and minority tensions (6), internal conflict (6), democratic accountability (6), and quality of the bureaucracy (6). Broad categories are: below 50 , very high risk; from 50 to 59.5 , high risk; from 60 to 84.5 , low risk; and from 85 to 100 , very low risk.

The use of the real exchange rate variable is an attempt to integrate exchange rate and competitiveness dimensions to determinants of trade. In a purely cross-sectional methodology, this variable does not make much sense since only movements over time of the real exchange rate have a real effect on levels of trade. Point values do not provide any information on whether local currencies are under- or over-valued. We correct for this cross-sectional bias by using the real annual exchange rate index for both the exporting and the importing country as provided by the IMF's INS database. In the spirit of methodology provided by Bergstrand (1985), the index is rebased on the means of the 1990-99 period. The underlying assumption is that the mean over the period corresponds to the equilibrium level for real exchange rates. By comparing coefficient estimates on the real exchange rate variable over the 1990 s, we may infer the effect of this variable on trade patterns. As the trade restrictiveness variable limits us to the 1997-99 period, the REER variable gives an approximation of the impact of real exchange rate movements over that three-year period compared to the "equilibrium" level in the 1990s.

The resulting "augmented" model specification is in the form:

$$
\begin{aligned}
\ln \left(X_{i j}\right) & =\alpha_{0}+\alpha_{1} \ln \left(Y_{i}\right)+\alpha_{2} \ln \left(Y_{j}\right)+\alpha_{3} \ln \left(N_{i}\right)+\alpha_{4} \ln \left(N_{j}\right)+\alpha_{5} \ln \left(D_{i j}\right)+\alpha_{6} \text { border } \\
& +\alpha_{7} \ln \left(\text { REER }_{i}\right)+\alpha_{8} \ln \left(\text { REER }_{j}\right)+\alpha_{9} \ln \left(\text { PolRisk }_{i}\right)+\alpha_{10} \ln \left(\text { PolRisk }_{j}\right) \\
& +\alpha_{11} \text { Trest }_{i}+\alpha_{12} \text { Trest }_{j}+\ln \left(\varepsilon_{i j}\right)
\end{aligned}
$$

The estimations (Table 3) largely confirm the intuitive direction of the relationship between our three variables of interest and bilateral trade. The coefficient for the real exchange rate of the exporting country is negative (i.e. real exchange rate appreciation negatively affects levels of exports). A country with an appreciated real exchange rate (in comparison to average 1990-99 levels) would export comparatively less than a country with a depreciated exchange rate. Somewhat counter intuitively, county $i$ 's exports also tend to be lower the more appreciated the real exchange rate is of the importing country $j$; however, this effect is much smaller and less significant. Coefficients for political risk seem to confirm that "risky" countries tend to trade less than "safe" countries. Finally, the trade restrictiveness index coefficients are significantly negative, indicating that the higher the trade restrictions the lower the level of exports. Again, it is mainly the degree of trade restriction in the exporting country that matters, 
presumably reflecting the impact of any export restrictions as well as any anti-export bias implied by import restrictions.

The increase in explanatory power is limited, compared to the standard specification for 1995-99. However, the relationships are found to be strongly significant, with highly robust (adjusted for heteroscedasticity) $t$-statistics. If we consider the exporting country, a 10 percent appreciation of the real exchange of the exporter would induce a 28.4 percent decrease in exports, if all other factors stay the same. A 10 percent reduction in political risk in the exporting country would increase exports by 19.3 percent. If the index of trade restrictiveness in the exporting country varies by 1 unit (toward a less restricted regime), the model suggests that exports would be increased by 20 percent. $^{10}$

\section{IV. "NormaL LeVels OF TRADE" IN THE MAShreQ}

\section{A. Exchange Rate, Trade Restrictions, and Political Risk: Where Does the Mashreq Stand?}

The above analysis has stressed the role of three factors in explaining levels of trade: trade restrictions, over/under-appreciation of local currencies, and political risk. Sample averages and Mashreq values are compared in Table 4. Figures in the table show that the impact of a reduction of Mashreq values to sample averages could be quite large.

This exercise highlights the potential of a considerable payoff for addressing macro policy and structural deficiencies. In particular, a fixation on currency pegs combined with sizable fiscal deficits has for many MENA countries, including in the Mashreq, resulted in sizable real appreciations. This in turn limits tradable growth, and creates incentives to control/ration foreign exchange through various means of import control. From a political economic point of view, rent-seekers in the protected sectors have greater weight than producers in the small export or potentially exporting sectors. This bias may be aggravated by the weight of the public sector in protected activities. Relating to this point, the political uncertainties that on average seem to be higher in the Mashreq than elsewhere are likely to discourage decisionmakers from upsetting the domestic political balance by challenging those benefiting from trade protection. Restrictive trade policies also contribute to limited international and intra-regional trade. As measured by the IMF trade restrictiveness index, the Mashreq countries are ranked as highly restrictive (Sharer and others, 1998) except for Israel and Jordan, which are in line with the world average (Table 5). Tariffs are relatively high in Egypt, Lebanon, and Syria. In Israel, and the West Bank and Gaza, complex tariff systems are a limit to trade. Non-tariff barriers are

\footnotetext{
${ }^{10}$ Such high elasticities may seem surprising. They are however comparable with coefficients estimated by Bergstrand (1985) for multi-industry trade flows (Bergstrand, 1985, p.148-151), and by Bergstrand (1989, p.479), for exchange rate deviations.
} 
an additional constraint to greater trade openness. Moreover, all countries (with Israel being relatively better endowed) have an important lack of infrastructure and trade services, ${ }^{11}$

\section{B. Assessing Levels of International Trade in the Mashreq}

As the next step, two dummy variables for the Mashreq are introduced to assess whether levels of Mashreq trade are "normal" given the value of the explanatory variables. Both dummies include the following countries: Egypt, Israel, Lebanon, Jordan, and Syria. The first dummy, Mashreq, accounts for international trade flows involving a country of that region. It takes value " 1 " when either the exporting or the partner country is a country of the Mashreq region, or when both are Mashreq countries, " 0 " otherwise. IntMashreq models intra-regional trade, and takes value " 1 " when both countries are Mashreq countries, " 0 " otherwise. For the period 1990-95, and 1995-99, we also assess levels of trade in the Mashreq using our standard specification for the gravity model. This allows us to quantify deviations of Mashreq countries' trade from expected levels.

The complete specification is:

$$
\begin{aligned}
\ln \left(X_{i j}\right) & =\alpha_{0}+\alpha_{1} \ln \left(Y_{i}\right)+\alpha_{2} \ln \left(Y_{j}\right)+\alpha_{3} \ln \left(N_{i}\right)+\alpha_{4} \ln \left(N_{j}\right)+\alpha_{5} \ln \left(D_{i j}\right)+\alpha_{6} \text { border } \\
& +\alpha_{7} \ln \left(\text { REER }_{i}\right)+\alpha_{8} \ln \left(\text { REER }_{j}\right)+\alpha_{9} \ln \left(\text { PolRisk }_{i}\right)+\alpha_{10} \ln \left(\text { PolRisk }_{j}\right) \\
& +\alpha_{11} \text { Trest }_{i}+\alpha_{12} \text { Trest }_{j}+\alpha_{13} \text { Mashreq }+\alpha_{14} \text { IntMashreq }+\ln \left(\varepsilon_{i j}\right)
\end{aligned}
$$

Results are reported in Table 6. For the period 1997-99, the Mashreq dummy variable, ${ }^{13}$ indicating the impact of being a Mashreq country on levels of bilateral trade, approximates 0 , and loses its statistical significance. This result contrasts with coefficients estimated without controlling for other variables, such as trade restrictions, political risk, and exchange rates. In this case, levels of both international trade and intra-regional trade are below expected levels for the Mashreq, as dummy coefficients are negative in both cases. For the period 1995-99, for example, expected levels of international trade are 39 percent above actual levels of trade in the Mashreq. Expected levels of intra-regional trade are 236 percent above actual levels, after controlling for economic and demographic size, and distance between partner countries. This tends to confirm that low levels of international trade in the Mashreq are explained by high

\footnotetext{
${ }^{11}$ For further detail on MENA countries' trade systems, see Oliva (2000).

${ }^{12}$ The risk of multicollinearity in the variables between the two dummies is limited because intra-regional trade is a very small fraction of total trade for the Mashreq.

${ }^{13}$ Again, we test for the presence of multicollinearity in the Mashreq and IntMashreq dummy variables. The fact that the dummy for international trade in the Mashreq includes intra-regional trade (for example, trade between Egypt and Jordan is recorded with a "1" for both dummies) may reduce the explanatory power of the regional trade dummy. The correlation between the two dummies nevertheless appears limited (the coefficient of correlation amounts to 15 percent), and multicollinearity does not appear to be a concern in our specification.
} 
trade restrictions, appreciation of the real exchange rate, and high degree of political uncertainty.

However, the regression (3) for 1997-99 indicates that levels of intra-regional trade are only partly explained by the three control variables. While the coefficient on the dummy variable for intra-regional trade diminishes from its value estimated without control variables, it remains significantly negative. This means that a significant fraction of the negative bias against intra-regional trade remains unexplained by our specification. One limit to our model may come from the imperfect definition of the political risk variable. The variable focuses mainly on domestic factors to political uncertainty. A more appropriate variable to the situation in the Mashreq would account for regional conflicts during the 1990s. Event variables are available but would not provide accurate estimates for a cross-country analysis.

Results of the regressions computed for individual years are reported in Appendix I. Overall, the model provides evidence that not only do Mashreq countries have low levels of international and intra-regional trade, but they have become less open to trade during the 1990s.

\section{Israel and Low Levels of Intra-Regional Trade}

We suspect that low levels of intra-regional trade may be explained by political tensions between Israel and the other Mashreq countries, which are not fully captured by the PolRisk variable. The last step of our analysis intends to measure the importance of Israel-Mashreq countries trade in explaining low levels of intra-regional trade.

We define a new dummy variable (IntMashreqIsrael) for intra-regional trade in the Mashreq, excluding Israel, which takes value " 1 " whenever exporting and partner countries are from the group including Egypt, Jordan, Lebanon, and Syria, value " 0 " otherwise. The Mashreq dummy remains the same, including Israel, and accounting for any bias in international trade for the Mashreq.

The specification of the model is:

$$
\begin{aligned}
\ln \left(X_{i j}\right) & =\alpha_{0}+\alpha_{1} \ln \left(Y_{i}\right)+\alpha_{2} \ln \left(Y_{j}\right)+\alpha_{3} \ln \left(N_{i}\right)+\alpha_{4} \ln \left(N_{j}\right)+\alpha_{5} \ln \left(D_{i j}\right)+\alpha_{6} \text { border } \\
& +\alpha_{7} \ln \left(\text { REER }_{i}\right)+\alpha_{8} \ln \left(\text { REER }_{j}\right)+\alpha_{9} \ln \left(\text { PolRisk }_{i}\right)+\alpha_{10} \ln \left(\text { PolRisk }_{j}\right) \\
& +\alpha_{11} \text { Trest }_{i}+\alpha_{12} \text { Trest }_{j}+\alpha_{13} \text { Mashreq }+\alpha_{15} \text { IntMashreqIsrael } \ln \left(\varepsilon_{i j}\right)
\end{aligned}
$$

The results of the estimations are provided in Table 7 . The Mashreq dummy remains close to 0 and insignificant, consistent with the results from Equation 3. The IntMashreqIsrael coefficients are significantly positive. They were negative when Israel was included in intra-regional trade. Arab countries in the Mashreq trade more between each other than would be expected from the gravity model. As measured by bilateral trade flows, the Mashreq countries, excluding Israel, are more integrated than suggested by the gravity model. This result suggests further that the negative bias to intra-regional trade in the Mashreq is fully explained by trade patterns between Israel and the neighboring Arab countries. 
For the three years of interest (i.e., 1997 through 1999), these results hold even when we do not control for real exchange rate, political uncertainty, and trade restrictions. Running the standard model specification with Mashreq dummies excluding Israel appears to confirm that levels of intra-regional trade in the Mashreq are higher than expected with the gravity model.

The somewhat surprising result that, once the Israel factor is accounted for, Mashreq countries are relatively closely integrated, is also confirmed by looking at trade intensity indices. Trade intensity indices between country $i$ and country $j$ are computed as follows: $\left(X_{i j} / X_{j}\right) /\left(X_{i} / X\right)$, where $X_{i j}$ are exports of country $i$ to country $\mathrm{j}, X_{j}$ are total exports for country $j, X_{i}$ are total exports of the rest of the world to country $j$, and $X$ is total world exports. Except for exports to and from Israel, the trade intensity indices for Mashreq countries are much above 1, showing that countries in the Mashreq export a larger proportion of their total exports to Mashreq countries than do the rest of the world. This pattern has been stable over time, as the comparison for 1990 and 1999 shows (Table 8).

Using the estimated coefficients in a predictive fashion, Table 9 report quantitative indications of what would be levels of intra-regional trade in the Mashreq if Mashreq countries were "average" countries as defined by our sample. We compare those levels with actual levels of bilateral trade. As expected, exports to and from Israel are significantly and consistently lower than would be expected by the gravity model. The total difference between expected and actual levels of intra-regional trade when Israel is included in the Mashreq increased to US\$948 million in 1999. When trade flows to/from Israel are disregarded, total actual bilateral flows in the region are higher than total expected flows, consistent with the fact that the dummy variable for intra-regional trade for the Mashreq becomes positive, indicating higher regional integration than expected with the model. Trade patterns between Lebanon and Syria account for the most part of this result. Syrian exports to Lebanon are much higher than expected levels, whereas Lebanese exports to Syria are below expected levels. When bilateral trade between Syria and Lebanon is excluded, actual levels of trade are almost equal to levels predicted by the model.

\section{Limits and Qualification of the Results}

The result that Mashreq countries, once Israel is excluded from the sample, are more integrated than expected with average estimates from our gravity model must take into consideration a number of limits of the empirical exercise.

In particular, the trade data from the IMF Direction of Trade database used to estimate the model includes trade in oil, which is significant for both Egypt and Syria (Table 10). While separate data on oil exports are not available in the Direction of Trade database (DOT), it appears quite possible that relatively high levels of intra-Mashreq trade partly reflect oil trade.

On the other hand, "resistance" to trade in the gravity model is represented by the distance between countries. In the Mashreq, "distance" may be a particularly imperfect measure of the actual economic resistance to trade in the region. Trade costs are high in the region as air, sea, road transportation, and telecommunications are poor among Mashreq countries 
(Havrylyshyn, 1997). Taking into account a broader measure of distance (transportation time door to door for example) would likely increase distances between Mashreq countries, and therefore lower expected levels of trade between these countries (as coefficients for the "distance" variable are negative). This would reinforce the final result that intra-regional trade is higher than "normal" levels defined by the gravity model.

Fischer (1992) alludes to another limit related to our empirical work, the fact that data for Mashreq countries are more than usually subject to errors. Trade between Israel and other Mashreq countries may be particularly problematic, as it is most often reported as zero or missing observation, against the possibility of a minimum degree of trade between the countries.

An additional limitation of our study is that DOT data on trade from and to Israel excludes trade from West Bank and Gaza (WBG) to the rest of the world; trade between Israel and WBG is also not recorded in DOT. As Israel probably trades significantly more with WBG than with other Mashreq countries, the large discrepancy between expected and realized intraregional trade would likely be reduced if WBG was entered separately into the model.

\section{Conclusion}

International and intra-regional trade in the Mashreq are below expected levels as defined statistically by a pure gravity model. Augmenting the pure gravity model by a number of policy variables provided evidence that low levels of international trade relative to levels predicted by the pure gravity model are largely explained by trade restrictions, real exchange rate appreciation, and political uncertainty. However, these three variables only partially explain relatively low levels of intra-regional trade. When Israel is not included in the Mashreq, intraregional trade in the Mashreq is found to be higher than predicted by the gravity model. Low levels of intra-regional trade are thus fully explained by limited trade between Israel and its neighbors.

The analysis strongly supports the argument that real appreciation of exchange rates and trade restrictions have been major impediments to international trade in the Mashreq. Political uncertainty also affects negatively international trade. Taking 1998 as a year of reference, a 10 percent appreciation of the real exchange would decrease volumes of export by 28.4 percent, if all other factors remain the same. On the other hand, a 10 percent reduction in political risk would increase volumes of exports by 19.3 percent. If the index of trade restrictiveness were to decline by 1 unit (toward a less restricted regime), the model suggests that exports would be increased by 20 percent. As the Mashreq countries (except Israel) are in the most restricted category for the trade restrictiveness index, the potential impact of comprehensive trade liberalization would be substantial.

Nonetheless, the combined effects of reducing trade restrictions, bringing down the real exchange rate, and reducing political risk on increasing intra-regional trade may be limited according to the model, as it would not address the main cause of the sizable difference found between estimated "normal" levels of intra-regional trade and current levels. When Israel is 
removed from the Mashreq dummy, we found that other Mashreq countries are well integrated, above expected levels. This does not preclude, however, that regional trade initiatives, such as the recently launched move toward an inter-Arab free trade area (General Arab Free Trade Area, GAFTA) will have a positive impact on intra-Mashreq trade by reducing the importance of "distance", i.e., reduce the implied economic distance. Such initiatives could also boost integration through affecting the Mashreq's score on the real exchange rate (REER), political risk, and global trade restrictiveness. For example, if GAFTA would reduce the trade restrictiveness index for the average Mashreq country to the population average, trade would increase by 15 percent. Intra-regional trade in the Mashreq would, however, still be significantly below expected levels as defined by the gravity model. This suggests further that an important benefit from a successful peace process would be to increase significantly intra-regional trade in the Mashreq, as the bulk of the difference between expected levels and current levels of trade is due to limited trade between Israel and the Arab countries of the Mashreq. 
Table 1. Mashreq and Comparators: Global Trade Indicators

\begin{tabular}{|c|c|c|c|c|c|c|}
\hline & \multicolumn{2}{|c|}{$\begin{array}{c}\text { Trade as Percent } \\
\text { of GDP } 1 /\end{array}$} & \multicolumn{2}{|c|}{$\begin{array}{l}\text { Total Exports as } \\
\text { Percent of GDP }\end{array}$} & \multicolumn{2}{|c|}{$\begin{array}{l}\text { Total Exports to Outside } \\
\text { Region as Percent of } \\
\text { of World Exports }\end{array}$} \\
\hline & 1980 & 1999 & 1980 & 1999 & 1980 & 1999 \\
\hline Mashreq (excluding Israel) & 67.87 & 54.58 & 15.86 & 13.38 & 0.34 & 0.16 \\
\hline Egypt & 35.34 & 22.35 & 13.61 & 4.05 & 0.17 & 0.06 \\
\hline Jordan & 72.11 & 68.39 & 12.68 & 17.05 & 0.02 & 0.02 \\
\hline Lebanon & 116.08 & 40.40 & 20.90 & 4.96 & 0.04 & 0.01 \\
\hline Syria & 47.96 & 43.73 & 16.24 & 20.76 & 0.11 & 0.06 \\
\hline West Bank and Gaza 2/ & $\ldots$ & 98.04 & $\ldots$ & 20.07 & $\ldots$ & 0.01 \\
\hline Israel & 73.37 & 57.54 & 26.71 & 26.09 & 0.30 & 0.46 \\
\hline Maghreb & 54.32 & 61.86 & 25.08 & 27.76 & 1.10 & 0.49 \\
\hline Algeria & 61.82 & 46.02 & 36.89 & 25.71 & 0.85 & 0.22 \\
\hline Morocco & 35.28 & 57.60 & 12.79 & 23.47 & 0.13 & 0.14 \\
\hline Tunisia & 65.86 & 81.95 & 25.56 & 34.11 & 0.12 & 0.13 \\
\hline GCC & 113.35 & 86.38 & 74.86 & 52.61 & 8.27 & 1.75 \\
\hline Bahrain & 230.92 & 141.74 & 117.52 & 100.45 & 0.15 & 0.11 \\
\hline Kuwait & 93.16 & 58.51 & 70.56 & 33.44 & 1.06 & 0.18 \\
\hline Oman & 79.25 & 78.65 & 51.94 & 47.41 & 0.18 & 0.11 \\
\hline Qatar & 86.22 & 67.89 & 67.83 & 46.48 & 0.28 & 0.10 \\
\hline Saudi Arabia & 88.55 & 53.34 & 68.34 & 33.56 & 5.45 & 0.78 \\
\hline U.A.E. & 101.99 & 118.17 & 72.97 & 54.33 & 1.15 & 0.46 \\
\hline Selected East Asia 3/ & 98.06 & 119.98 & 48.08 & 67.53 & 5.20 & 10.39 \\
\hline Selected Latin America 4/ & 19.39 & 32.21 & 8.35 & 15.07 & 2.23 & 3.44 \\
\hline Developing countries & 60.64 & 67.97 & 24.00 & 27.23 & 21.62 & 20.35 \\
\hline Western Hemisphere & 69.94 & 71.38 & 29.73 & 26.38 & 4.38 & 4.54 \\
\hline Africa & 44.45 & 60.02 & 17.59 & 23.67 & 3.35 & 1.68 \\
\hline
\end{tabular}

Sources: International Monetary Fund, Direction of Trade Statistics; and WEO database (Fall 2000).

Note: Regional numbers in first four columns are arithmetic averages.

1/ Exports plus imports.

2/ For West Bank and Gaza Strip total exports and imports of goods and services were used.

3/ People's Republic of China, Hong Kong SAR, Indonesia, Republic of Korea, Malaysia, Philippines, Singapore, and Thailand.

4/ Argentina, Brazil, and Mexico. 
Table 2. Intra-Regional Trade in the Mashreq Region

\begin{tabular}{|c|c|c|c|c|c|c|}
\hline & \multicolumn{6}{|c|}{$\begin{array}{l}\text { Intra-Regional Exports } \\
\text { (In percent of total exports) }\end{array}$} \\
\hline & 1995 & 1996 & 1997 & 1998 & 1999 & $\begin{array}{l}\text { Average } \\
1995-99\end{array}$ \\
\hline Industrial countries & 70.9 & 70.5 & 70.0 & 72.4 & 72.6 & 71.3 \\
\hline Of which $\mathrm{EU}$ & 63.0 & 62.1 & 58.9 & 61.2 & 62.1 & 61.5 \\
\hline $\begin{array}{l}\text { Developing countries } \\
\text { Of which }\end{array}$ & 43.5 & 43.8 & 44.4 & 41.3 & 39.4 & 42.5 \\
\hline MENA & 9.5 & 8.4 & 6.9 & 7.5 & 6.9 & 7.8 \\
\hline Mashreq & 3.2 & 3.8 & 3.4 & 2.1 & 1.6 & 2.8 \\
\hline Maghreb & 0.5 & 0.5 & 0.5 & 0.2 & 0.2 & 0.4 \\
\hline Africa & 8.9 & 9.0 & 8.7 & 10.3 & 9.4 & 9.2 \\
\hline Asia & 40.6 & 41.0 & 41.6 & 37.4 & 37.0 & 39.5 \\
\hline Western Hemisphere & 20.0 & 20.2 & 20.5 & 20.1 & 17.8 & 19.7 \\
\hline
\end{tabular}

Sources: International Monetary Fund, Direction of Trade Statistics. 
Table 3. Estimates for the Standard and Augmented Specifications

( $t$-statistics in parenthesis)

\begin{tabular}{|c|c|c|c|c|c|c|c|c|}
\hline & $1990-941 / 2 /$ & & $1995-993 /$ & & $1997-994 /$ & & $1997-994 /$ & \\
\hline $\mathrm{C}$ & 2.42 & $(15.9)$ & 1.94 & (13.44) & 1.35 & (6.9) & 8.31 & $(6.0)$ \\
\hline $\log (Y i)$ & 1.47 & $(178.9)$ & 1.44 & $(162.16)$ & 1.48 & $(121.6)$ & 1.07 & $(50.6)$ \\
\hline $\log (Y j)$ & 1.11 & $(126.3)$ & 1.14 & $(124.2)$ & 1.17 & $(93.6)$ & 0.98 & $(44.4)$ \\
\hline $\log (\mathrm{Ni})$ & 0.26 & $(22.6)$ & -0.21 & $(18.7)$ & -0.18 & $(-12,1)$ & 0.24 & (9.7) \\
\hline $\log (\mathrm{Nj})$ & 0.15 & (12.2) & -0.09 & $(7.5)$ & -0.10 & $(-5.8)$ & 0.09 & (3.5) \\
\hline $\log (\mathrm{Dij})$ & -1.19 & $(-69.1)$ & -1.2 & $(-72.0)$ & -1.19 & $(-51.8)$ & -1.23 & $(-51.4)$ \\
\hline Border & 0.94 & $(10.3)$ & 1.08 & $(12.5)$ & 1.03 & $(8.7)$ & 0.71 & $(5.8)$ \\
\hline Log (REERi) & & & & & & & -2.84 & $(20.0)$ \\
\hline Log (REERj) & & & & & & & -0.87 & $(-6.0)$ \\
\hline Log (PolRiski) & & & & & & & 1.93 & (11.4) \\
\hline Log (PolRiskj) & & & & & & & 1.09 & $(6.8)$ \\
\hline Tresti & & & & & & & -0.20 & $(-19.9)$ \\
\hline Trestj & & & & & & & -0.07 & $(-6.6)$ \\
\hline Adjusted R-2 & 0.65 & & 0.64 & & 0.63 & & 0.63 & \\
\hline
\end{tabular}

1/ Sample: 32,486 observations, 734 observations excluded (tests show that observations are missing at random). For data sources, see text.

2/ All variables are found significant at the 1 percent degree of confidence, with robust standard deviations (i.e., adjusted for heteroscedasticity) unless otherwise noted. ${ }^{* * *}$ : insignificant at the 10 percent degree of confidence.

3/ Sample: 32,445 observations; 775 observations excluded.

4/ Sample: 18,343 observations; 1589 observations excluded. 
Table 4. Sample Averages and Mashreq Values on Control Variables, 1999

\begin{tabular}{|c|c|c|c|c|c|c|}
\hline & REER & $\begin{array}{c}\text { Impact 1/ } \\
\text { (In percent) }\end{array}$ & PolRisk & $\begin{array}{c}\text { Impact } \\
\text { (In percent) }\end{array}$ & Trest & $\begin{array}{c}\text { Impact } \\
\text { (In percent) }\end{array}$ \\
\hline Average & 103.0 & .. & 70.6 & $\ldots$ & 4.7 & $\ldots$ \\
\hline Egypt & 124.7 & 49.42 & 64.6 & -17.93 & 8.0 & 66.0 \\
\hline Israel & 102.3 & -1.94 & 58.8 & -38.73 & 4.0 & -14.0 \\
\hline Jordan & 109.8 & 17.59 & 71.6 & 2.70 & 7.0 & 46.0 \\
\hline Lebanon & n.a. & n.a. & 57.3 & -44.80 & 7.0 & 46.0 \\
\hline Syria & 93.7 & -28.19 & 67.8 & -7.97 & 10.0 & 106.0 \\
\hline
\end{tabular}

1/ Impact that a reduction of Mashreq levels to sample averages would have on trade for the Mashreq, using the coefficients estimated with the augmented model. 
Table 5. Mashreq and Comparator Countries: Trade Restrictions, 1999 1/

\begin{tabular}{lccc}
\hline & Overall & $\begin{array}{c}\text { Nontariff } \\
\text { Barriers (NTBs) }\end{array}$ & Tariff \\
\hline Mashreq 2/ & 7.8 & 2.3 & 4.3 \\
Maghreb 3/ & 7.7 & 2.0 & 4.7 \\
GCC 4/ & 2.8 & 1.5 & 1.3 \\
Sub-Saharan Africa & 4.9 & 1.6 & 3.2 \\
Selected Latin America 5/ & 4.3 & 1.8 & 2.0 \\
Selected East Asia 6/ & 3.7 & 1.7 & 1.7 \\
World & 4.4 & 1.7 & 2.2 \\
& & & \\
\hline
\end{tabular}

Sources: International Monetary Fund, Trade Restrictions database.

1/ Overall index 1-4 unrestricted, 5-6 moderate restrictions, 7. 10 restrictive; NTB index 1-3; tariff index 1-5. For details on the methodology, see IMF, "Trade Liberalization in IMF-Supported Programs," World Economic and Financial Surveys, Washington, D.C., 1998.

2/ Average of the Mashreq countries: Arab Republic of Egypt, Jordan, Lebanon, and Syrian Arab Republic

3/ Average of the Maghreb countries: Algeria, Morocco, and Tunisia.

4/ Average of the Gulf Cooperation Council (GCC) countries: Bahrain, Kuwait, Oman, Qatar, Saudi Arabia, and the United Arab Emirates.

5/ Average of selected Latin American countries: Argentina, Brazil, Chile, and Mexico.

6/ Average of selected East Asian countries: Malaysia, Singapore, and Thailand. 
Table 6. Estimates for the Standard and Augmented Specifications with Mashreq Dummy Variables ( $t$-statistics in parenthesis)

\begin{tabular}{|c|c|c|c|c|c|c|c|c|}
\hline & $1990-941 / 2 /$ & & $1995-993 /$ & & $1997-99 \quad 4 /$ & & $1997-99 \quad 4 /$ & \\
\hline $\mathrm{C}$ & 2.74 & (18.1) & 2.39 & $(16.7)$ & 1.80 & $(9.2)$ & 8.44 & $(6.2)$ \\
\hline $\log (Y i)$ & 1.46 & $(176.3)$ & 1.43 & $(160.4)$ & 1.47 & $(120.3)$ & 1.07 & $(50.6)$ \\
\hline $\log (Y j)$ & 1.1 & $(123.9)$ & 1.13 & (122.6) & 1.16 & $(92.4)$ & 0.98 & $(44.7)$ \\
\hline $\log (\mathrm{Ni})$ & -0.26 & $(-22.7)$ & -0.21 & $(-18.9)$ & -0.18 & $(-12.2)$ & -0.23 & $(-9.6)$ \\
\hline $\log (\mathrm{Nj})$ & -0.15 & $(-12.2)$ & -0.09 & $(-7.7)$ & -0.10 & $(-6.0)$ & -0.09 & $(-3.4)$ \\
\hline $\log (\mathrm{Dij})$ & -1.22 & $(-71.4)$ & -1.24 & $(-74.9)$ & -1.22 & $(-53.6)$ & -1.24 & $(-51.7)$ \\
\hline Border & 1.02 & $(12.2)$ & 1.18 & $(15.1)$ & 1.14 & $(10.3)$ & 0.82 & $(7.0)$ \\
\hline Log (REERi) & & & & & & & -2.83 & $(19.7)$ \\
\hline $\log ($ REERj) & & & & & & & -0.86 & $(-5.9)$ \\
\hline Log (PolRiski) & & & & & & & 1.91 & $(11.2)$ \\
\hline Log (PolRiskj) & & & & & & & 1.07 & $(6.8)$ \\
\hline Tresti & & & & & & & -0.20 & $(-19.4)$ \\
\hline Trestj & & & & & & & -0.07 & $(-6.3)$ \\
\hline Mashreq & -0.21 & -4.5 & -0.39 & -8.7 & -0.39 & -6.6 & $0.04 * *$ & 0.6 \\
\hline IntMashreq & -1.62 & -3.7 & -2.36 & -5.3 & -2.36 & -4.0 & -1.70 & -2.8 \\
\hline Adjusted R-2 & 0.65 & & 0.64 & & 0.63 & & 0.63 & \\
\hline
\end{tabular}

1/ Sample: 32,486 observations; 734 observations excluded (tests show that observations are missing at random). For data sources, see text.

2/ All variables are found significant at the 1 percent degree of confidence, with robust standard deviations (i.e., adjusted for heteroscedasticity), unless otherwise noted. ***: insignificant at the 10 percent degree of confidence.

3/ Sample: 32,445 observations; 775 observations excluded.

4/ Sample: 18,343 observations; 1,589 observations excluded. 
Table 7. Estimates for the Augmented Specification with Mashreq Dummy Variables, Excluding Israel

$(t$-statistics in parenthesis)

\begin{tabular}{|c|c|c|c|c|c|c|c|c|}
\hline & $1990-94 \quad 1 / 2 /$ & & $1995-99 \quad 3 /$ & & $1997-99 \quad 4 /$ & & $1997.994 /$ & \\
\hline $\mathrm{C}$ & 2.55 & $(16.5)$ & 2.23 & $(15.4)$ & 1.64 & $(8.3)$ & 8.32 & (6.1) \\
\hline $\log (\mathrm{Yi})$ & 1.46 & $(176.7)$ & 1.43 & $(160.6)$ & 1.47 & $(120.4)$ & 1.07 & $(50.3)$ \\
\hline $\log (Y j)$ & 1.10 & $(124.4)$ & 1.13 & $(122.8)$ & 1.16 & $(92.6)$ & 0.98 & $(44.5)$ \\
\hline $\log (\mathrm{Ni})$ & -0.26 & $(-22.8)$ & -0.21 & $(-18.9)$ & -0.18 & $(-12.2)$ & -0.24 & $(-9.7)$ \\
\hline $\log (N j)$ & -0.15 & $(-12.3)$ & -0.09 & $(-7.7)$ & -0.10 & $(-6.0)$ & -0.09 & $(-3.5)$ \\
\hline $\log (D i j)$ & -1.20 & $(-69.1)$ & -1.22 & $(-73.2)$ & -1.21 & $(-52.5)$ & -1.23 & $(-51.0)$ \\
\hline Border & 0.85 & $(9.2)$ & 1.00 & $(11.6)$ & 0.96 & (7.9) & 0.67 & (5.4) \\
\hline Log (REERi) & & & & & & & -2.84 & $(-19.7)$ \\
\hline Log (REERj) & & & & & & & -0.88 & $(-6.0)$ \\
\hline Log (PolRiski) & & & & & & & 1.93 & (11.2) \\
\hline I.og (PolRiskj) & & & & & & & 1.09 & (6.9) \\
\hline Tresti & & & & & & & -0.21 & $(-19.6)$ \\
\hline Trestj & & & & & & & -0.07 & $(-6.5)$ \\
\hline Mashreq & -0.26 & $(-5.7)$ & -0.45 & $(-9.9)$ & -0.46 & $(-7.5)$ & $0.01 * * *$ & $(0.1)$ \\
\hline IntMashreqIsrael & 1.52 & (11.9) & 0.78 & $(6.4)$ & 0.78 & $(5.1)$ & 1.32 & (8.1) \\
\hline Adjusted R-2 & 0.65 & & 0.65 & & 0.62 & & 0.63 & \\
\hline
\end{tabular}

1/ Sample: 32,486 obscrvations, 734 observations excluded (tests show that observations are missing at random). For data sources, see text.

2/ All variables are found significant at the ! percent degree of confidence, with robust standard deviations (i.e., adjusted for heteroscedasticity) unless otherwise noted. ${ }^{* * *}$ : insigniticant at the 10 percent degree of confidence.

3/ Sample: 32,445 observations; 775 observations excluded.

4/ Sample: 18,343 observations; 1,589 observations excluded. 
Table 8. Trade Intensity Index for Exports in the Mashreq

Export data from the reporter country to the partner country

\begin{tabular}{|c|c|c|c|c|c|c|c|c|c|c|}
\hline & \multicolumn{5}{|c|}{1990} & \multicolumn{5}{|c|}{1999} \\
\hline & Egypt & Israel & Jordan & Lebanon & Syria & Egypt & Israel & Jordan & Lebanon & Syria \\
\hline Exporting & & & & & & & & & & \\
\hline Egypt & $\ldots$ & 16.6 & 7.8 & 5.4 & 6.5 & $\ldots$ & 10.2 & 10.3 & 7.5 & 16.4 \\
\hline Israel & 0.1 & $\ldots$ & 0.0 & n.a. & 0.0 & 0.6 & $\ldots$ & 1.4 & n.a. & 0.0 \\
\hline Jordan & 4.8 & 0.0 & $\ldots$ & 21.8 & 19.9 & 5.0 & 2.9 & $\ldots$ & 32.9 & 18.4 \\
\hline Lebanon & 8.1 & n.a. & 42.3 & $\ldots$ & 48.3 & 6.3 & n.a. & 62.4 & .. & 38.6 \\
\hline Syria & 3.1 & 0.0 & 7.4 & 95.7 & $\ldots$ & 2.9 & 0.0 & 19.2 & 45.6 & $\ldots$ \\
\hline
\end{tabular}

Source: IMF, Direction of Trade Statistics (Fall 2000). 
Table 9. Comparison: Expected Versus Actual Intra-Regional Exports, 1999 1/

(In billions of U.S. dollars)

\begin{tabular}{|c|c|c|c|c|c|c|c|}
\hline & & \multicolumn{3}{|c|}{ Standard Specification } & \multicolumn{3}{|c|}{ Augmented Specification } \\
\hline & & $\mathrm{E} 2 /$ & R 3/ & (R-E) & $\mathrm{E} 2 /$ & $\mathrm{R} 3 /$ & (R-E) \\
\hline Egypt & Israel & 959 & 187 & -772 & 277 & 187 & -90 \\
\hline Egypt & Jordan & 38 & 21 & -16 & 16 & 21 & 5 \\
\hline Egypt & Lebanon & 28 & 23 & -5 & 7 & 23 & 16 \\
\hline Egypt & Syria & 24 & 42 & 18 & 12 & 42 & 30 \\
\hline Israel & Egypt & 1,219 & 55 & $-1,164$ & 468 & 55 & -413 \\
\hline Israel & Jordan & 457 & 21 & -436 & 256 & 21 & -235 \\
\hline Israel & Lebanon & 478 & 0 & -478 & 119 & 0 & -119 \\
\hline Israel & Syria & 438 & 0 & -438 & 218 & 0 & -218 \\
\hline Jordan & Egypt & 22 & 21 & -1 & 14 & 21 & 7 \\
\hline Jordan & Israel & 211 & 19 & -193 & 133 & 19 & -114 \\
\hline Jordan & Lebanon & 11 & 36 & 25 & 5 & 36 & 31 \\
\hline Jordan & Syria & 12 & 17 & 4 & 11 & 17 & 6 \\
\hline Lebanon & Egypt & 22 & 16 & -5 & n.a. & 16 & n.a. \\
\hline Lebanon & Israel & 289 & 0 & -289 & n.a. & 0 & n.a. \\
\hline Lebanon & Jordan & 14 & 28 & 14 & n.a. & 28 & n.a. \\
\hline Lebanon & Syria & 99 & 49 & -49 & n.a. & 49 & n.a. \\
\hline Syria & Egypt & 16 & 22 & 6 & 11 & 22 & 11 \\
\hline Syria & Israel & 235 & 0 & -235 & 125 & 0 & -125 \\
\hline Syria & Jordan & 14 & 45 & 30 & 12 & 45 & 33 \\
\hline \multirow[t]{2}{*}{ Syria } & Lebanon & 87 & 262 & 174 & 35 & 262 & 227 \\
\hline & & \multicolumn{6}{|c|}{ (Total of difference between real and expected levels of bilateral trade) } \\
\hline \multicolumn{3}{|c|}{ Including Israel } & & $-3,809$ & & & -948 \\
\hline \multicolumn{3}{|c|}{ Excluding Israel } & & 195 & & & 366 \\
\hline \multicolumn{3}{|c|}{ (Excluding Lebanon-Syria flows) } & & 70 & & & 139 \\
\hline
\end{tabular}

Source: IMF, Direction of Trade Statistics (November 2000) and Tables 5-7.

1/ Calculations for expected levels are made using the standard specification of the gravity model and the corresponding coefficients.

2/ $\mathrm{E}=$ Expected levels of trade.

$3 / \mathrm{R}=$ Actual levels of trade. 
Table 10. Trade in Oil in the Mashreq

Oil Exports in the Mashreq (as a percentage of total exports)

\begin{tabular}{lrrrrrrrrrr}
\hline & 1990 & 1991 & 1992 & 1993 & 1994 & 1995 & 1996 & 1997 & 1998 & 1999 \\
& & & & & & & & & \\
\hline & & & & & & & & & & \\
Egypt & 39.1 & 60.0 & 52.2 & 61.8 & 53.1 & 43.9 & 48.3 & 48.2 & 33.7 & 22.5 \\
Israel & 0.0 & 0.0 & 0.0 & 0.0 & 0.0 & 0.0 & 0.0 & 0.0 & 0.0 & 0.0 \\
Jordan & 0.0 & 0.0 & 0.0 & 0.0 & 0.0 & 0.0 & 0.0 & 0.0 & 0.0 & 0.0 \\
Lebanon & 0.0 & 0.0 & 0.0 & 0.0 & 0.0 & 0.0 & 0.0 & 0.0 & 0.0 & 0.0 \\
Syria & 45.9 & 53.4 & 69.6 & 60.0 & 59.9 & 64.8 & 65.8 & 61.8 & 51.4 & 61.5 \\
& & & & & & & & & & \\
\hline
\end{tabular}

Source: IMF, World Economic Outlook database (Fall 2000). 
Table 11. Estimates for Individual Years, Excluding Regional Dummy Variables

(Estimates for individual years)

\begin{tabular}{|c|c|c|c|c|c|c|c|c|c|c|}
\hline Variable $1 /$ & 1990 & 1991 & 1992 & 1993 & 1994 & 1995 & 1996 & 1997 & 1998 & 1999 \\
\hline $\mathrm{C}$ & 1.47 & 2.66 & 1.86 & 2.04 & 3.26 & 2.88 & 2.63 & 12.27 & 11.54 & 9.51 \\
\hline$t$-Statistic & 3.37 & 6.22 & 4.45 & 6.07 & 9.59 & 8.49 & 7.75 & -4.23 & 5.05 & 4.49 \\
\hline $\log (Y i)$ & 1.59 & 1.56 & 1.52 & 1.49 & 1.44 & 1.46 & 1.51 & 1.06 & 1.18 & 1.01 \\
\hline$i$-Statistic & 70.15 & 69.90 & 72.32 & 69.80 & 71.16 & $64.7 \mathrm{I}$ & 71.22 & 25.84 & 33.81 & 27.78 \\
\hline $\log (Y j)$ & 1.17 & 1.15 & 1.14 & 1.14 & 1.14 & 1.18 & 1.18 & 0.98 & 0.98 & 0.97 \\
\hline$t$-Statistic & 48.09 & 48.04 & 48.76 & 51.76 & 55.17 & 51.78 & 53.89 & 22.13 & 26.65 & 27.52 \\
\hline $\log (\mathrm{Ni})$ & -0.34 & -0.31 & -0.26 & -0.22 & -0.23 & -0.25 & -0.31 & -0.24 & -0.19 & -0.23 \\
\hline$t$-Statistic & -10.57 & -9.79 & -8.60 & -7.94 & -8.24 & -8.65 & -11.47 & -5.53 & -4.69 & -5.27 \\
\hline $\log (\mathbf{N j})$ & -0.20 & -0.18 & -0.18 & -0.14 & -0.11 & -0.11 & -0.10 & -0.08 & -0.08 & -0.12 \\
\hline$t$-Statistic & -5.85 & -5.20 & -5.37 & -5.03 & -3.93 & -3.81 & -3.23 & -1.56 & -1.83 & -2.86 \\
\hline $\log (\mathrm{Dij})$ & -1.13 & -1.27 & -1.18 & -1.20 & -1.34 & -1.34 & -1.34 & -1.25 & -1.26 & -1.21 \\
\hline$t$-Statistic & -23.08 & -26.47 & -24.94 & -30.37 & -34.16 & -33.77 & -34.57 & -26.60 & -30.28 & -33.02 \\
\hline Border & 1.17 & 0.90 & 0.91 & 0.64 & 0.99 & 1.07 & 1.07 & 0.56 & 0.56 & 0.97 \\
\hline$t$-Statistic & 4.96 & 3.79 & 3.66 & 3.33 & 4.80 & 5.46 & 5.60 & 2.36 & 2.42 & 5.73 \\
\hline Log (REERi) & & & & & & & & -2.67 & -2.87 & -3.61 \\
\hline$t$-Statistic & & & & & & & & -13.34 & -14.08 & -15.57 \\
\hline $\log ($ RlEERj) & & & & & & & & -0.62 & -0.69 & -1.33 \\
\hline$t$-Statistic & & & & & & & & -3.03 & -3.06 & -6.08 \\
\hline Log (PolRiski) & & & & & & & & 3.17 & 1.26 & 2.40 \\
\hline t-Statistic & & & & & & & & 8.95 & 4.70 & 8.04 \\
\hline Log (PolRiskj) & & & & & & & & 1.14 & 0.79 & 1.70 \\
\hline t-Statistic & & & & & & & & 3.44 & 3.05 & 6.34 \\
\hline Tresti & & & & & & & & -0.21 & -0.19 & -0.17 \\
\hline$t$-Statistic & & & & & & & & -10.40 & -10.94 & -10.35 \\
\hline Trestj & & & & & & & & -0.04 & -0.07 & -0.09 \\
\hline$t$-Statistic & & & & & & & & -1.78 & -4.14 & -5.03 \\
\hline Adjusted R-squared & 0.63 & 0.63 & 0.61 & 0.65 & 0.64 & 0.63 & 0.63 & 0.62 & 0.63 & 0.66 \\
\hline Included observations & 4947 & 4948 & 5418 & 6003 & 6222 & 6304 & 6351 & 5313 & 5998 & 6004 \\
\hline Excluded observations & 1696 & 1695 & 1225 & 640 & 421 & 339 & 292 & 1330 & 645 & 639 \\
\hline
\end{tabular}

1/ White Heteroscedasticity-Consistent Standard Errors \& Covariance. All variables are found significant at the 1 percent degrec of confidence, with robust standard deviations (i.e. adjusted for heteroscedasticity), unless otherwise noted.

***: insignificant at the 10 percent degree of confidence. 


\section{Table 12. Estimates for Individual Years, Including Mashreq Dummy Variables}

(Estimates for individual years including Mashreq dummy variables)

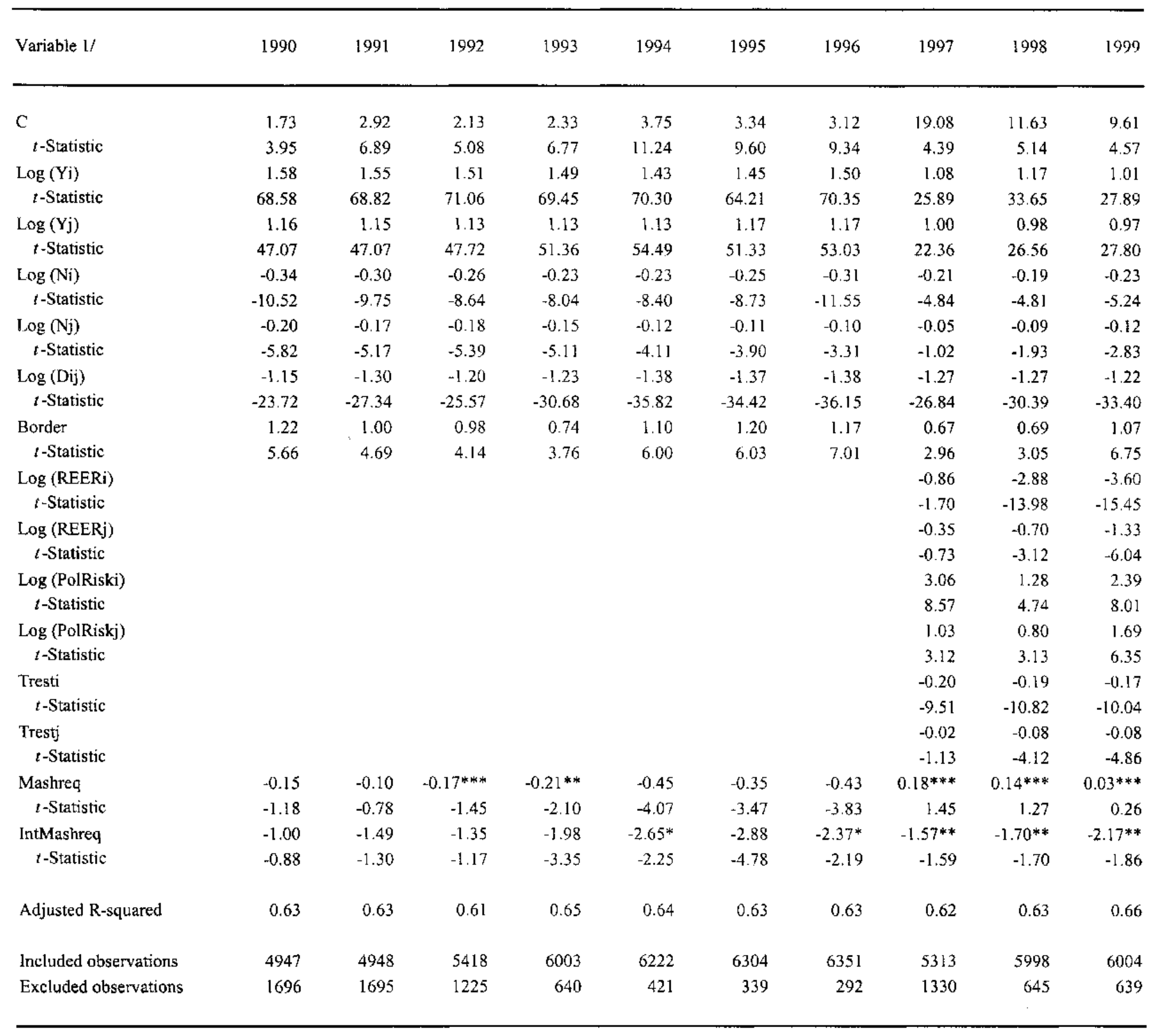

Source:

1/ White Heteroscedasticity-Consistent Standard Errors \& Covariance. All variables are found significant at the 1 percent degree of confidence, with robust standard deviations (i.e. adjusted for heteroscedasticity), unless otherwise noted. ***: non significant at the 10 percent degree of confidence. 
Table 13. Countries Included in the Gravity Model Sample 1/

\begin{tabular}{|c|c|c|c|c|}
\hline 1. Algeria & 21. Denmark & 41. Kazakhstan & 61. Russia & 81. Venezuela \\
\hline 2. Argentina & 22. Dominican Republic & 42. Kenya & 62. Saudi Arabia & 82. Zimbabwe \\
\hline 3. Australia & 23. Ecuador & 43. Korea & 63. Singapore & \\
\hline 4. Austria & 24. Egypt & 44. Lebanon & 64. Slovak Republic & \\
\hline 5. Bahrain & 25. El Salvador & 45. Lithuania & 65. South Africa & \\
\hline 6. Belarus & 26. Finland & 46. Malaysia & 66. Spain & \\
\hline 7. Belgium & 27. France & 47. Mexico & 67. Sri Lanka & \\
\hline 8. Bolivia & 28. Georgia & 48. Morocco & 68. Sweden & \\
\hline 9. Brazil & 29. Germany & 49. Netherlands & 69. Switzerland & \\
\hline 10. Bulgaria & 30. Greece & 50. New Zealand & 70. Syrian Arab Republic & \\
\hline 11. Cameroon & 31. Guatemala & 51. Nigeria & 71. Tanzania & \\
\hline 12. Canada & 32. Hungary & 52. Norway & 72. Thailand & \\
\hline 13. Chile & 33. India & 53. Pakistan & 73. Tunisia & \\
\hline 14. China, P.R.: Mainland & 34. Indonesia & 54. Panama & 74. Turkey & \\
\hline 15. China, P.R.: Hong Kong & 35. Iran, 1. R. of & 55. Paraguay & 75. Ukraine & \\
\hline 16. Colombia & 36. Ireland & 56. Peru & 76. United Arab Emirates & \\
\hline 17. Costa Rica & 37. Israel & 57. Philippines & 77. United Kingdom & \\
\hline 18. Cote d'Ivoire & 38. Italy & 58. Poland & 78. United States & \\
\hline 19. Croatia & 39. Japan & 59. Portugal & 79. Uruguay & \\
\hline 20. Czech Republic & 40. Jordan & 60. Romania & 80. Uzbckistan & \\
\hline
\end{tabular}

1/ The country choice is based upon three criteria: gross national product supcrior to US\$5 billion; total population superior to 2 million; and GNP per capita superior to US\$500. 


\section{Bibliography}

Alcaly, R.E., 1967, "Aggregation and Gravity Models: Some Empirical Evidence," Journal of Regional Science, Vol. 7 (Summer): pp. 61-73.

Al-Atrash, H., and T. Yousef, 2000, "Intra-Arab Trade: Is It Too Little?" IMF Working Paper 00/10 (Washington: International Monetary Fund).

Anderson, J., 1979, "A Theoretical Foundation for the Gravity Model," American Economic Review, Vol. 69 no. 1, pp. 106-116.

Beckerman, W., 1956, "Distance and Pattern of Inter-European Trade," Review of Economics and Statistics, Vol. 38, pp. 31-40.

Bergstrand, J., 1985, "The Gravity Equation in International Trade: Some Microeconomic Foundations and Empirical Evidence," Review of Economics and Statistics, s, Vol. 67 (3), pp. 474-481.

Bergstrand, J., 1989, "The Generalized Gravity Equation, Monopolistic Competition, and the Factor-Proportions Theory of Trade," Review of Economics and Statistics, Vol. 71 (1), pp. 143-153.

Black, W.R., 1971, "The Utility of the Gravity Model and Estimates of its Parameters in Commodity Flow Studies," Proceedings of the Association of American Geographers, Vol. 3, pp. 28-32.

Blavy, R., P. Duran, and K. Enders, 2001, "Potential Implications of Recent Trade Initiatives and Middle East Peace on Growth and Economic Integration in the Mashreq," mimeo, (Washington: International Monetary Fund).

Deardoff, A., 1995, "The Prospects for Economic Development in the Middle East After Peace," mimeo, University of Michigan, Ann Arbor, Michigan.

Ekholm, K., J. Torstensson, and R. Torstensson, 1995, "Prospects for Trade in the Middle East and North Africa: An Econometric Analysis," paper for the Economic Research Forum Conference on Liberalization of Trade and Foreign Investment, Bogacizu University, Istanbul.

Fischer, S., 1993, "Prospects for Regional Integration in the Middle East," in: New Dimensions in Regional Integration, ed. by J. De Melo and A. Panagariya, CEPR (CUP), (Cambridge: Cambridge University Press).

Frankel, J.E., and S-J. Wei, 1995, "Open Regionalism in a World of Continental Trade Blocs," NBER WP, WP 5272 (September). 
Frankel, J., E. Stein, and S-J. Wei, 1996a, "Regional Trading Arrangements: Natural or Supernatural," American Economic Review, Vol. 86 No. 2, pp. 52-56.

Frankel, J., E. Stein, and S-J. Wei, 1996b, "Regional Trading Arrangements: Natural or Supernatural," NBER WP, WP 5431 (January).

Havrylyshyn, O. 1997, "A Global Integration Strategy for the Mediterranean Countries: Open Trade and Market Reforms," Middle Eastern Department, (Washington: International Monetary Fund).

Helliwell, J., 1998, How Much Do National Barriers Matter?, ed. Washington, Brookings Institutional Press.

Helpman, E., 1984, "Increasing Returns, Imperfect Markets, and Trade Theory," in Handbook of International Economics, Vol. 1, ed. by R. Jones and P. Kenen, Amsterdam: North Holland. .

Linneman, H., 1969, "Trade Flows and Geographical Distance, or the Importance of Being Neighbors," in Towards Balanced International Growth: Essays Presented to J. Tinbergen, ed. by H.C. Bos, 1969 (Amsterdam, North Holland). .

Oliva, M., 2000, "Estimation of Trade Protection in Middle East and North African Countries," IMF Working Paper 00/27 (Washington: International Monetary Fund).

Pollins, B., 1989, "Conflict, Cooperation, and Commerce: The Effect of International Political Interactions on Bilateral Trade Flows," American Journal of Political Science, Vol. 33, No. 3, pp. 737-761.

Sharer, R., P. Sorsa, and N. Calika , 1998, "Trade Liberalization in Fund-Supported Programs, World Economic and Financial Surveys (Washington: International Monetary Fund).

Soloaga, I., and A. Winters, 1999, "Regionalism in the Nineties: What Effect on Trade," CEPR DP. 2183, (June), London.

Srivastava, R., and R. Green, 1986, "Determinants of Bilateral Trade Flows," Journal of Business, Vol. 59, No. 4, pp. 623-639.

World Bank, 1993, "Developing the Occupied Territories: An Investment in Peace," Vol. 1, (September), (Washington: The World Bank).

Yeats, A., 1996, "Export Prospects of Middle Eastern Countries: A Post-Uruguay Round Analysis," World Bank Policy Research Working Paper, No. 1571, (February) (Washington: The World Bank). 